\title{
Penumbuhan Karakter Islami melalui Pembelajaran Fisika Berbasis Integrasi Sains-Islam
}

\author{
Ahmad Khoiri ${ }^{1}$, Qori Agussuryani ${ }^{2}$, Puji Hartini ${ }^{3}$ \\ ${ }^{1,2}$ Program Studi Pendidikan Fisika Universitas Sains Al-Qur'an Jawa Tengah di Wonosobo; \\ E-mail: akhoiri@unsiq.ac.id \\ ${ }^{3}$ SMK Takhasuss Al-Qur'an Wonosobo
}

Diterima: 1 April 2017. Disetujui: 22 Mei 2017. Dipublikasikan: Juni 2017

\begin{abstract}
The Classroom Action Research aims to find out physics learning based on science-Islamic integration can improve learning outcomes and foster the Islamic character of class XI RPL 1 SMK Takhassus Al-Qur'an. The Action research is done in two cycles namely: (1) planning, (2) implementation of corrective action, (3) observation, and (4) reflection. The Research Instrument through Test for learning result data, Observation to observe the implementation of learning and questionnaire of religious attitude and social attitude and Documentation. The results of research shows the application of physics-based learning science-Islamic integration can improve learning outcomes, religious and social attitudes. The Percentage mastery is 74 to 90. Religious attitudes is increased from 72 to 79 and social attitudes is increased from 67 to 76 as evidenced by indicators not cheating or giving cheat and reporting learning activities in a transparent manner. The implementation of learning-based integration of science-Islamic can improve learning outcomes and Islamic characters in the form of honesty and cooperation of students on the physics in the concept of fluid.
\end{abstract}

\begin{abstract}
Abstrak
Penelitian Tindakan Kelas bertujuan mengetahui pembelajaran fisika berbasis integrasi sains-islami dapat meningkatkan hasil belajar serta menumbuhkan karakter islami siswa kelas XI RPL 1 SMK Takhassus AlQur'an. Penelitian tindakan dilakukan dua siklus yakni: (1) perencanaan, (2) pelaksanaan tindakan perbaikan, (3) observasi, dan (4) refleksi. Instrumen Penelitian melalui Tes untuk data hasil belajar, Observasi untuk mengamati pelaksanaan pembelajaran dan angket sikap religious dan sikap sosial serta Dokumentasi. Hasil Penelitian menunjukan penerapan pembelajaran fisika berbasis integrasi sains-islami dapat meningkatkan hasil belajar, sikap religius dan sikap sosial. Prosentase ketuntasan 74 menjadi 90. Sikap religius meningkat dari 72 menjadi 79 serta sikap sosial meningkat dari 67 menjadi 76 yang dibuktikan dengan indicator tidak mencontek atau memberikan contekan serta melaporkan kegiatan belajar secara transparan. Penerapan pembelajaran berbasis integrasi sains-islami dapat meningkatkan hasil belajar dan karakter islami berupa kejujuran dan kerjasama siswa pada mata pelajaran fisika konsep fluida.
\end{abstract}

Kata kunci: fluida, karakter islami dan pembelajaran sains-islam.

(C) 2017 URPI, FTK UIN Raden Intan Lampung

\section{PENDAHULUAN}

Pendidikan memuat tujuan berupa gambaran tentang nilai-nilai yang baik, luhur, pantas, benar, dan indah untuk kehidupan. Fokus pada pendidikan sains (IPA) baik fisika, biologi atau kimia yang bertujuan agar siswa memiliki keyakinan keteraturan alam Ciptaan-Nya dan keagungan Tuhan Yang Maha Esa.

Menitipkan tujuan di atas pada pelajaran sains adalah sungguh rasional dan tepat. Karena, banyak ayat-ayat Al-
Quran yang memerintahkan agar kita (manusia) memikirkan sebagian tandatanda Kebesaran dan Keagungan-Nya melalui penciptaan langit dan bumi, juga berbagai fenomena dan peristiwa alam (lihat misalnya QS Ali Imran,3: 190-191; Nuh, 71:13-20; An-Naml, 27:70). Pembahasan materi pendidikan Islam yang terkadang cenderung mengabaikan persoalan-persoalan keduniawian, misalnya sains dan teknologi. kajian dalam 
al-Quran sebagai landasan teologis ummat Islam banyak bicara tentang kosmologis dan kesemestaan (Masduki, 2015).

SMK Takhassus Al-Qur'an merupakan sekolah kejuruan yang mempunyai ciri khas sebagai sekolah pesantren yang sangat menjunjung tinggi nilai-nilai islami. Visi misi sekolah yang berkarakter islami harus diwujudkan dalam segala aspek penyelenggaraan pendidikan di SMK dengan mengedepankan karakterkarakter agama termasuk pembelajaran sains/fisika melalui Al-Qur'an yang sangat menekankan pentingnya membaca, mengamati dan merenungkan fenomenafenomena alam. Al-Qur'an mengambil contoh dari kosmologi, fisika, biologi, ilmu kedokteran dan lainnya sebagai tanda kekuasaan Allah agar menjadi bahan perenungan manusia.

Fakhry memberi definisi mengenai konsep Islamisasi terhadap ilmu pengetahuan. Islamisasi berarti upaya memberikan makna keagamaan seperti pada sains, sembari menyadari bahwa sains dapat dikembangkan dalam konteks keagamaan maupun non keagamaan (Fakhry, 2010). Waston mengatakan bahwa pelajaran sains/fisika memiliki karakter religius, kejujuran, kecerdasan, ketangguhan, kepedulian, demokratis, ingin tahu, berpikir logis, kritis, kreatif, dan inovatif, bergaya hidup sehat, kepercaya diri, menghargai keberagaman, disiplin, kemandirian, bertanggung jawab, dan cinta ilmu (Waston, 2014). Penekanan secara umum adalah berpikir logis, kritis, kreatif, dan inovatif yaitu berpikir dan melakukan sesuatu secara kenyataan atau logika untuk menghasilkan cara atau hasil baru dan termutakhir dari yang telah dimiliki (Ali, 2015). Semua indikator tersebut terangkum dalam ranah sikap religius, sikap sosial dan keterampilan siswa.

Minimnya karakter islami siswa menjadi tanggungjawab besar guru dalam membangun generasi muda. Keadaan sangat memprihatinkan pada kondisi siswa-siswa sekarang. Siswa masih banyak yang malas sekolah, kurang disiplin waktu, terlambat masuk sekolah atau kelas, kerapian berpakaian siswa yang kurang. Hal ini sesuai dengan (Masduki, 2015), usaha pembelajaran pendidikan agama Islam di sekolah diharapkan mampu membentuk kesalehan pribadi dan sekaligus kesalehan sosial. Akan tetapi, pendidikan agama diharapkan jangan sampai (1) menumbuhkan semangat fanatisme; (2) menumbuhkan sikap intoleran di kalangan peserta didik dan masyarakat; dan (3) memperlemah kerukunan hidup beragama serta persatuan dan kesatuan nasional.

Berdasarkan penelitian (Aji \& Halal, 2014) tentang pengembangan modul IPA berbasis karakter islami melalui pendekatan saintifik pada tema rotasi dan revolusi bumi sebagai implementasi kurikulum 2013, menunjukan hasil belajar siswa meningkat setelah mengikuti proses pembelajaran berbasis karakter islami melalui pendekatan saintifik. Menyisipkan nilai-nilai agama dalam pembelajaran sains sebagai upaya alternatif memagari aqidah siswa.

Perlunya menyisipkan nilai-nilai agama (ayat-ayat kauniyyah) dalam pembelajaran sains dapat didasarkan pada beberapa alasan: (1) Kehampaan spiritual dalam pendidikan sains di sekolah dan dunia ilmiah harus dihindari dan dicarikan solusinya; (2) Fenomena alam yang ada dan terjadi di bumi dan langit adalah obyek kajian sains dan sekaligus merupakan obyek tafakkur terhadap Allah Swt; (3) Sains yang "menolak" Allah dapat menyebabkan manusia yang "bergelut" dengan sains dapat mengalami berbagai krisis multidimensional; (4) Pemaparan sains dalam buku-buku pelajaran (teoriteori dan penjelasannya), yang didasari materialisme, telah menghilangkan Allah sebagai pencipta; (5) Ayat-ayat Al-Qur'an (Kauniyiah) yang dinyatakan secara garis besar akan dapat dipahami dengan lebih baik bila didukung oleh pemahaman sains; dan (6) Sebagai ikhtiar untuk "memagari" sains agar para siswa tidak terjerumus ke 
dalam ajaran-ajaran yang bertentangan dengan akidah dan keimanan agama. Secara umum, sains Islam bertujuan untuk mengantarkan seseorang kepada pemahaman yang lebih mendalam terhadap ayat-ayat Allah, baik ayat qauliyah maupun ayat kauniyah (Irwandani, 2016).

Berdasarkan masalah tentang pembenahan karakter islami yang harus dimiliki siswa, pada penelitian tindakan kelas ini penulis akan meneliti fokus pada pembelajaran fisika berbasis integrasi sains-islam untuk menumbuhkan karakter islami meliputi: sikap spiritual, sikap sosial dan keterampilan siswa di SMK Takhassus Al-Qur'an. Tujuan penelitian ini untuk mengetahui Pembelajaran Fisika berbasis integrasi sains-islami dapat dapat meningkatkan hasil belajar serta menumbuhkan karakter islami siswa.

\section{METODE PENELITIAN}

Metode Penelitian yang digunakan adalah Penelitian Tindakan. Setting penelitian di SMK Takhassus Al-Qur'an, beralamat di jalan Kalibeber Mojotengah Wonosobo yang bervisi: "Unggul Dalam Prestasi Berdasarkan Iman dan Taqwa". Waktu penelitian dilakukan bulan Agustus hingga September 2016, pada Semester Gasal Tahun Pelajaran 2016/2017. Subjek Penelitian peserta didik kelas XI RPL 1 sebanyak 31 siswa.

Indikator keberhasilan menetapkan kriteria keberhasilan dalam segala aspek sekurang kurangnya 75\% dari aspek yang diteliti (Mulyasa, 2010). Sehingga dalam penelitian ini dapat diuraikan sesuai dengan variabel penelitian, yaitu: Minimal $75 \%$ peserta didik mengalami peningkatan sikap religius (tindakan konkret seperti kejujuran), memiliki sikap sosial berupa kerjasama kelompok, mendapat nilai hasil belajar diatas batas ketuntasan.

Secara umum, tindakan penelitian dilaksanakan secara bersiklus. Setiap siklus terdiri dari 4 tahapan, yaitu perencanaan, pelaksanaan tindakan, observasi, dan refleksi. Siklus pelaksanaan tindakan ini dapat dilukiskan sebagai berikut (Mulyasa, 2010):

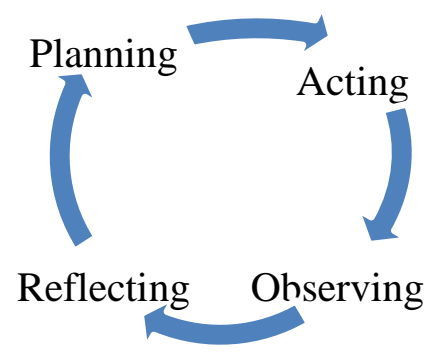

Gambar 1. Alur Penelitian Tindakan Kelas

Langkah tindakan yang akan dilakukan adalah:

1. Perencanaan (Planning)

a. Guru menyiapkan syair lagu sains bernuansa shalawat yang akan dinyanyikan peserta didik untuk membangkitkan motivasi

b. Guru menyiapkan beberapa lembar kerja siswa berbasis intergrasi sainsislami

c. Peserta didik masing-masing diberikan LKS

d. Peserta didik diminta untuk mengamati fenomena sains dalam LKS

e. Peserta didik diminta untuk berkelompok sesuai pembagian.

f. Guru membimbing peserta didik yang mengalami kesulitan.

g. Peserta didik diminta untuk mempresentasikan kerjasama kelompok.

h. Peserta didik mencari dalil-dali dalam al-qur'an yang masih ada hubungannya dengan materi.

i. Peneliti melaksanakan refleksi bersama guru pembimbing atas penerapan pembelajaran yang telah dilaksanakan.

j. Peneliti melaksanakan evaluasi bersama guru pembimbing mengenai perkembangan penguasaan konsep pada materi yang dibahas.

2. Pelaksanaan (Acting) 
1) Peserta didik menyanyikan lagu sains bernuansa shalawat.

2) Guru membagikan LKS berbasis integrasi sains-islami

3) Guru membantu peserta didik dalam pembelajaran.

4) Guru memotivasi peserta didik untuk merenungi keagungan Tuhan melalui fenomena yang ditampilkan dalam LKS.

5) Peserta didik bekerjasama dengan kelompok masing-masing, dan saling memberi tahu antara temannya untu saling peduli.

6) Salah seorang peserta didik dari masing-masing kategori diminta untuk mempresentasikan hasil diskusi dengan penuh kejujuran.

7) Beberapa peserta didik diminta mencari ayat-ayat al-qur'an yang berhubungan dengan materi sains.

3. Pengamatan (Observing)

1) Apabila ada kesalahan dalam pembelajaran, peserta didik dibantu oleh guru setelah didiskusikan terlebih dahulu dengan observer.

2) Observer bersama guru pembimbing melakukan pengamatan dan berkeliling memantaunya serta melakukan analisis tentang kelebihan dan kekurangan pada tindakan I tersebut.

3) Hasil pengamatan ditulis peneliti sebagai bahan pembuatan refleksi.

4) Pengamatan terhadap proses pembelajaran dilakukan secara terus menerus hingga proses evaluasi.

4. Refleksi (Reflecting)

1) Observer dengan guru pembimbing melakukan diskusi untuk merefleksi

2) Pada tindakan I telah memantau peserta didik dalam diksusi kelompok. Namun masih perlu peningkatan yang lebih intensif mengingat masih banyak kekurangan dalam menerapkan model pembelajaran sains berbasis integrasi sains-islami.

3) Untuk meningkatkan penguasaan konsep sains diupayakan pembimbingan yang intensif dalam hal cara belajar peserta didik.
4) pembimbingan kepada peserta didik dilakukan oleh guru pembimbing bersama-sama observer.

5) Perlu adanya siklus II untuk lebih mengoptimalkan peran guru untuk membimbing peserta didik yang masih belum meingkatkan sikap religious dan sikap social.

6) Hasil evaluasi pembelajaran berupa pemahaman konsep sains yang belum memenuhi KKM perlu dilanjutkan siklus kedua.

\section{a. Teknik dan Alat Pengumpulan Data}

Instrumen pengumpulan data pada penelitian tindakan ini yaitu:

1) Tes digunakan untuk memperoleh data hasil belajar berupa pemahaman konsep sains menggunakan metode pretest dan posttest pembelajaran sains berbasis integrasi sains-islami.

2) Observasi. Metode observasi yaitu metode pengamatan yang didukung dengan pengumpulan dan pencatatan data secara sistematis terhadap objek yang diteliti (Nasution, 2010). Observasi digunakan sebagai konfirmasi kesesuaian data yang diberikan siswa dari pengisian angket sikap religious berupa kejujuran siswa.

3) Kuesioner (Angket) merupakan teknik pengumpulan data yang dilakukan dengan cara memberi seperangkat pertanyaan atau pernyataan tertulis kepada responden untuk dijawabnya (Sugiyono, 2006).

4) Metode Dokumentasi adalah informasi yang didokumentasikan dalam rekaman baik gambar/foto, suara, tulisan/manuskrip, atau yang lainnya.

\section{b. Validasi Data}

Penelitian ini menggunakan Valiadasi Konstruk dengan para ahli dibidangnya yaitu guru tim fisika, data yang divalidasi yaitu: soal tes hasil belajar serta lembar instrumen angket kejujuran dan kerjasama.

\section{c. Analisis Data}


Penelitian ini menggunakan analisis diskriptif yaitu: membandingkan hasil belajar (nilai tes) antar siklus maupun dengan indikator kinerja sebelum dan sesudah perlakuan, hasil observasi, angket, dokumentasi dan refleksi pada tiap siklus.

\section{HASIL DAN PEMBAHASAN}

\section{Deskripsi Kondisi Awal}

Mengkaji dan mengembangkan sains dan teknologi dapat bernilai ibadah bahkan menjadi nilai perjuangan di sisi Allah (Rusdiana, 2015). Berdasarkan implementasi pembelajaran fisika terintegrasi sains-Islam pada siswa kelas XI RPL SMK Takhassus Al-Qur'an Wonosobo Tahun Pelajaran 2016/2017 sangat memprihatinkan terbukti dengan banyaknya siswa yang membolos sekolah alasan yang tidak jujur, tidak mau mengakui kesalahannya. Hal ini dapat diketahui dari data observasi kondisi awal siswa. Selain karakter Islami siswa yang memprihatinkan, terdapat hasil belajar yang kurang maksimal yang diikuti oleh 31 siswa tersebut, sebagian besar nilai siswa masih berada di bawah KKM. Pencapaian prosentase ketuntasan belajar hanya $51 \%$. Nilai tertinggi sudah mencapai 86 , nilai terendah 43 , dan nilai rerata hanya 61,64 Untuk memperjelas tentang hasil belajar siswa pada kondisi awal ini, maka berikut ini sajikan tabel hasil belajar siswa pada ulangan harian I.

Tabel 1. Nilai Kondisi Awal

\begin{tabular}{llc}
\hline No & \multicolumn{1}{c}{ Uraian } & Nilai \\
\hline 1 & Nilai tertinggi & 86 \\
2 & Nilai terendah & 43 \\
3 & Nilai rerata & 61,64 \\
\hline 4 & Prosentase ketuntasan belajar & $51 \%$ \\
\hline
\end{tabular}

\footnotetext{
Sebelum dilaksanakan penelitian, guru belum menerapkan model pembelajaran yang menumbuhkan karakter Islami siswa dalam belajar. Jalannya proses pembelajaran lebih banyak didominasi oleh guru, sedangkan siswa lebih banyak diperlakukan sebagai obyek
}

belajar, sehingga cenderung kurang aktif dan berperan. Dalam penelitian tindakan ini guru menyajikan materi fisika tentang "fluida", guru lebih banyak menghubungkan materi dengan kajian AlQur'an bertujuan memberikan sentuhansentuhan nuansa Islami. Hal ini yang nantinya berpengaruh terdapat sikap siswa dalam aktivitas belajar dan bukan hanya sekedar pemahaman materi saja namun sikap-sikap religius dan sikap sosial dapat digali melalui pembelajaran ini.

\section{Deskripsi Hasil Siklus I Perencanaan}

1) Pendahuluan: Pembentukan kelompok, penyampaian tujuan pembelajaran, dan penjelasan tentang model pembelajaran yang akan diterapkan serta memberikan sentuhan-sentuhan islami dengan mendengarkan lagu islami untuk menumbuhkan sikap religius.

2) Kegiatan inti: Menyajkan materi tentang "fluida" dengan menerapkan pembelajaran terintegrasi sains-islam.

3) Penutup: Melaksanakan tes hasil belajar dan pengisian kuisioner.

\section{Pelaksanaan Tindakan}

1) Pendahuluan dengan pembentukan kelompok, menyampaikan tujuan pembelajaran dan model pembelajaran yang akan diterapkan.

2) Kegiatan inti terdapat 5 (lima) fase meliputi:

Fase 1:

Menjelaskan kompetensi dasar; Memotivasi siswa dan mengaitkan materi sebelumnya; Menjelaskan kepada siswa bagaimana belajar dengan pendekatan kompetensi yang terfokus pada kajian islami.

Fase 2:

Membantu/membimbing siswa dalam belajar dan bekerjasama; Guru membagi siawa pada kelompokkelompok kecil yaitu masing-masing kelompok berjumlah 4 anak dan menjelaskan kegiatan yang akan 
dilaksanakan; Mendorong dan melatih aktivitas belajar dan kerjasama kelompok dalam berdiskusi; Diskusinya untuk menemukan dan menentukan poin-poin penting pada materi tersebut sekaligus memperdalam penguasaan materi secara bersama-sama dalam satu kelompok; Berada dalam tugas, Dalam diskusi itu mereka juga merangkum materi-materi yang penting-penting yang nantinya akan menjadi bahan pokok dalam melaksanakan presentasi di depan kelas; Mengambil giliran dan berbagi tugas, setiap anggota kelompok mempunyai kewajiban bersama untuk mengerjakan tugasnya; Bertanya, Dapat mengajukan pertanyaan jika belum jelas Mendengarkan dengan aktif dan Memberikan dan menghargai kontribusi.

Fase 3:

Mengevaluasi dan mereview hasil kerja kelompok; Mengevaluasi kerja kelompok dengan cara mencocokan bersama konsep yang benar sekaligus dijelaskan oleh guru untuk memperdalam pemahaman.

Fase 4:

Membimbing siswa mempresentasikan kerja kelompok; Masing-masing kelompok mempresentasikan hasil diskusinya didepan kelas dengan urutan dari kelompok terkecil ke kelompok yang besar. Kelompok lain mendengarkan dam memperhatikan kelompok yang sedang presentasi; Dalam mempresentasikan setiap kelompok semua siswa mendapat giliran sesuai dengan pembagian kelompok tersebut, dengan maksud agar semua siswa aktif dalam pembelajaranya.

Fase 5:

Membimbing siswa membuat kesimpulan; Kemudian guru membimbing siswa dalam membuat kesimpulan secara bersama-sama setelah semua kelompok presentasi.

3) Penutup dengan pelaksanaan tes tertulis dan pengisian angket/kuisioner.

\section{Hasil Pengamatan Siklus 1}

Pada siklus I, persentase ketuntasan belajar sebesar $74 \%$, nilai tertinggi sebesar 89 nilai terendahnya sebesar 53 dan nilai rerata sebesar 69. Untuk mempermudah dalam memahami pencapaian hasil belajar pada siklus I tersebut, maka berikut ini disajikan tabel tentang hasil belajar pada siklus I.

Tabel 2. Nilai Siklus 1

\begin{tabular}{ccc}
\hline No & Uraian & Nilai \\
\hline 1 & Nilai tertinggi & 89 \\
2 & Nilai terendah & 53 \\
3 & Nilai rerata & 69 \\
4 & Prosentase ketuntasan & $74 \%$ \\
& belajar & \\
\hline
\end{tabular}

Hasil pengamatan tentang sikap religius dan sikap sosial yang diperoleh dari pengisian angket kepada siswa terdiri dari 10 soal angket sikap religius dan 12 soal angket sikap sosial, dapat disajikan dalam bentuk tabel berikut:

Tabel 3. Data hasil sikap religius dan sikap sosial

\begin{tabular}{|c|c|c|c|}
\hline No & Uraian & $\begin{array}{c}\text { Sikap } \\
\text { Religius }\end{array}$ & $\begin{array}{l}\text { sikap } \\
\text { sosial }\end{array}$ \\
\hline 1 & Nilai tertinggi & 88 & 88 \\
\hline 2 & Nilai terendah & 62 & 52 \\
\hline 3 & Nilai rerata & 72 & 67 \\
\hline
\end{tabular}

Hasil data siklus 1 sikap religius dan sikap sosial masih kategori cukup karena belum mencapai nilai 75. Ada beberapa faktor yang mempengaruhinya:

1) Karakter siswa tidak dapat diamati dalam waktu yang cepat dan singkat, memerlukan proses panjang, sehingga kurun waktu 1 minggu-4 minggu belum dapat diamati dengan jelas.

2) Siswa belum terbiasa dan terpola pembelajaran yang diterapkan.

3) Perlu adanya perbaikan dan peningkatan hasil ke siklus berikutnya. 
Selanjutnya dalam pengelolaan pembelajaran fisika berbasis integrasi sains-islam dengan pendekatan Problem Based Learning dapat disajikan dalam tabel berikut:

Tabel 4. Hasil observasi pengelolaan Pembelajaran Siklus 1

\begin{tabular}{lcl}
\hline Aspek & $\begin{array}{l}\text { Prosentase } \\
\text { Keterlak- } \\
\text { sanaan }\end{array}$ & Kategori \\
\hline Persiapan & $75 \%$ & Cukup \\
Pelaksanaan & $75 \%$ & Cukup \\
Fase 1 & $50 \%$ & Kurang \\
Fase 2 & $75 \%$ & Cukup \\
Fase 3 & $100 \%$ & Baik Sekali \\
Fase 4 & $75 \%$ & Cukup \\
Fase 5 & $75 \%$ & Cukup \\
Pengeloaan Waktu & $92 \%$ & Baik \\
Suasana Kelas & $77 \%$ & Cukup \\
Rata-rata & & \\
\hline
\end{tabular}

Pengelolaan pembelajaran pada siklus 1 masih terdapat bagian yang perlu diperbaiki terutama pada fase dua kategori kurang yaitu Membantu/membimbing siswa dalam belajar dan bekerjasama, karena pada siklus 1 pola pembelajaran masih bersifat mandiri.

\section{1) Refleksi}

Deskriptif komparatif antara kondisi awal dengan siklus I sebagai bahan tindak lanjut untuk diperbaiki ke siklus II.

a. Tindakan

Kondisi Awal: Dalam proses pembelajaran belum menerapkan pembelajaran terintegrasi sains-islam.

Siklus I: Dalam proses pembelajaran sudah menerapkan pembelajaran terintegrasi sains-islam

b. Proses Pembelajaran

Kondisi Awal: Siswa kurang aktif, beberapa siswa mengantuk, kreativitas siswa dalam belajar masih rendah serta sikap religious dan sosial belum diamati.

Siklus I: Sebagian besar siswa aktif, jumlah siswa yang mengantuk berkurang, dan kreativitas siswa dalam belajar nampak antusias, sikap religious dan sosial telah diamati.

c. Hasil Belajar

Kondisi awal Ketuntasan sejumlah $51 \%$ Siklus I: Ketuntasan sejumlah $74 \%$.

d. Karakter Islami

Kondisi Awal: Belum pernah diamati.

Siklus I: Telah diamati dari hal yang kecil yaitu kejujuran dan kerjasama sosial.

Berdasarkan deskriptif data bahwa dengan pendekatan pembelajaran yang terintegrasi sains-islam dapat meningkatkan keaktifan siswa dalam proses pembelajaran, dapat mengurangi jumlah siswa yang mengantuk, malas sekolah, melatih disiplin dan dapat meningkatkan kreativitas siswa dalam proses belajar. Berikut simulasi lembar kerja siswa yang dapat meningkatkan karakter islami.

Konsep sains tentang fluida adalah zat yang dapat mengalir contohnya zat cair dan gas. Cabang ilmu fisika yang mempelajari fluida adalah mekanika fluida baik statis atau dinamis, salah satunya pada fluida dinamis pada angin. Sedangkan konsep al-qur'an dijelaskan pada (Q.S Al Jaatsiyah: 5) yang artinya: "Dan pada pergantian malam dan siang dan hujan yang diturunkan Allah dari langit lalu dihidupkan-Nya dengan air hujan itu bumi sesudah matinya; dan pada perkisaran angin terdapat tanda-tanda (kekuasaan Allah) bagi kaum yang berakal". Sedangkan terintegrasi islami pada Keterturan alam semesta meliputi siang malam, air hujan dan angin.

Untuk lebih jelasnya dapat disajikan dalam skema tabel berikut: 
Tabel 5. Skema Konsep Fluida yang terintegrasi Al-Qur'an

\begin{tabular}{|c|c|c|c|}
\hline $\begin{array}{l}\text { Konsep } \\
\text { Fluida } \\
\end{array}$ & Sains & Al-Qur'an & Islami \\
\hline $\begin{array}{l}\text { Pengertian } \\
\text { Fluida }\end{array}$ & $\begin{array}{l}\text { Fluida adalah zat yang } \\
\text { dapat mengalir } \\
\text { contohnya zat cair dan } \\
\text { gas. Cabang ilmu fisika } \\
\text { yang mempelajari fluida } \\
\text { adalah mekanika fluida } \\
\text { baik statis atau dinamis, } \\
\text { salah satunya pada fluida } \\
\text { dinamis pada angin. }\end{array}$ & $\begin{array}{l}\text { Dan pada pergantian malam dan siang dan } \\
\text { hujan yang diturunkan Allah dari langit lalu } \\
\text { dihidupkan-Nya dengan air hujan itu bumi } \\
\text { sesudah matinya; dan pada perkisaran angin } \\
\text { terdapat tanda-tanda (kekuasaan Allah) bagi } \\
\text { kaum yang berakal. (Q.S (Al Jaatsiyah: } 5)\end{array}$ & $\begin{array}{l}\text { Keterturan } \\
\text { alam } \\
\text { semesta } \\
\text { meliputi } \\
\text { siang } \\
\text { malam, air } \\
\text { hujan dan } \\
\text { angin. }\end{array}$ \\
\hline $\begin{array}{l}\text { Hukum } \\
\text { Pascal }\end{array}$ & $\begin{array}{l}\text { Tekanan yang diberikan } \\
\text { pada suatu zat cair } \\
\text { didalam ruang tertutup } \\
\text { diteruskan sama ke } \\
\text { segala arah } \\
\mathrm{F}_{1} / \mathrm{A}_{1}=\mathrm{F}_{2} / \mathrm{A}_{2}\end{array}$ & $\begin{array}{l}\text { Atau siapakah yang telah menciptakan langit } \\
\text { dan bumi dan yang menurunkan air untukmu } \\
\text { dari langit, lalu Kami tumbuhkan dengan air itu } \\
\text { kebun-kebun yang berpemandangan indah, } \\
\text { yang kamu sekali-kali tidak mampu } \\
\text { menumbuhkan pohon-pohonnya? Apakah } \\
\text { disamping Allah ada tuhan (yang lain)? Bahkan } \\
\text { (sebenarnya) mereka adalah orang-orang yang } \\
\text { menyimpang (dari kebenaran). } \\
\text { (QS. An-Naml/27:60) }\end{array}$ & $\begin{array}{l}\text { Air sebagai } \\
\text { sumber } \\
\text { kehidupan }\end{array}$ \\
\hline $\begin{array}{l}\text { Hukum } \\
\text { Archimides }\end{array}$ & $\begin{array}{l}\text { Jika sebuah benda } \\
\text { dimasukkan ke dalam } \\
\text { fluida seluruhnya / } \\
\text { sebagian, benda tersebut } \\
\text { akan mendapat gaya } \\
\text { angkat ke atas sebesar } \\
\text { berat fluida yang } \\
\text { dipindahkan. } \\
\mathrm{F}_{\mathrm{A}}=\rho . \mathrm{g} . \mathrm{v} \\
\mathrm{W}_{\text {air }}=\mathrm{w}-\mathrm{FA}\end{array}$ & $\begin{array}{l}\text { Atau seperti gelap gulita di lautan yang dalam, } \\
\text { yang diliputi oleh ombak, yang di atasnya } \\
\text { ombak (pula), di atasnya (lagi) awan; gelap } \\
\text { gulita yang tindih-bertindih, apabila dia } \\
\text { mengeluarkan tangannya, tiadalah dia dapat } \\
\text { melihatnya, (dan) barangsiapa yang tiada } \\
\text { diberi cahaya (petunjuk) oleh Allah tiadalah dia } \\
\text { mempunyai cahaya sedikitpun. (QS: an-Nur: } \\
\text { 40) }\end{array}$ & $\begin{array}{l}\text { Keajaiban } \\
\text { dalam } \\
\text { lautan }\end{array}$ \\
\hline $\begin{array}{l}\text { Penerapan } \\
\text { hukum } \\
\text { Archimides }\end{array}$ & 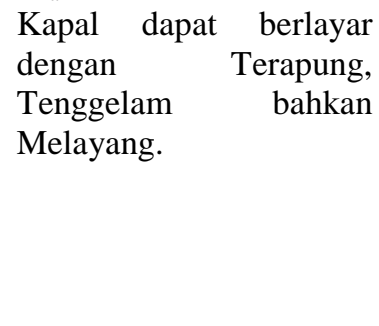 & $\begin{array}{l}\text { "Dan diantara tanda -tanda kekuasaanNya } \\
\text { ialah bahwa Dia mengirimkan angin sebagai } \\
\text { pembawa berita gembira dan untuk merasakan } \\
\text { kepadamu sebagian dari rahmatNya dan supaya } \\
\text { kapal dapat berlayar dengan perintahNya dan } \\
\text { supaya kamu dapat mencari karuniaNya, } \\
\text { mudah-mudahan kamu bersyukur." Qs: Ar- } \\
\text { Ruum: } 46)\end{array}$ & $\begin{array}{l}\text { Karunia } \\
\text { Tuhan } \\
\text { melalui } \\
\text { teknologi } \\
\text { masa kini. }\end{array}$ \\
\hline
\end{tabular}

Tabel 6. Refleksi siklus 1

\begin{tabular}{lll}
\hline No & \multicolumn{1}{c}{ Uraian } & \\
\hline 1 & Proses & Refleksi \\
& Pembelajaran & $\begin{array}{l}\text { Siswa meningkat, sikap religious (jarang yang mencontek) dan sikap sosial mulai } \\
\text { tumbuh yang dibuktikan dengan kerjasama kelompok yang solid. }\end{array}$
\end{tabular}


2 Hasil belajar

$3 \quad$ Karakter Islami Kejujuran

$4 \quad$ Kerjasama Kelompok
Nilai tertinggi naik $10 \%$ dari 86 menjadi 89;

Nilai terendah naik 32\% dari 43 menjadi 53;

Nilai rerata naik $25 \%$ dari 61 menjadi 69;

Ketuntasan belajar naik $46 \%$ dari $51 \%$ menjadi $74 \%$.

Nilai rata-rata 72 kategori cukup, perlu ditingkatkan ke siklus 2

Nilai rata-rata 67 kategori cukup perlu ditingkatkan ke siklus 2
Berdasarkan Tabel 5 dan Tabel 6 . Bahwa peningkatan kualitas proses pembelajaran tersebut mengakibatkan terjadinya peningkatan pada hasil belajar siswa. Nilai tertinggi mengalami peningkatan sebesar $10 \%$ dari 86 menjadi 89 nilai terendah mengalami peningkatan sebesar 32\% dari 43 menjadi 53; nilai rerata mengalami peningkatan $25 \%$ dari 61 menjadi 69; dan pencapaian prosentase ketuntasan belajar juga mengalami peningkatan sebesar $23 \%$ dari $51 \%$ menjadi $74 \%$.

Peningkatan hasil belajar dari kondisi awal ke siklus pertama tersebut tergolong penigkatan yang cukup tinggi. Namun hal ini sangat wajar, karena pada kondisi awal guru lebih banyak mengajar dengan metode ceramah sehingga siswa tidak aktif dan berkesan dalam proses pembelajaran. Sedangkan pada siklus pertama guru menerapkan model pembelajaran terintegrasi sains-Islami sehingga dapat menumbuhkan sikap religius dan sikap sosial dalam proses pembelajaran. Untuk mempermudah dalam memahami tentang hasil refleksi pada siklus pertama.

Untuk mengetahui tingkat kejujuran siswa, kemudian dilakukan observasi kesesuaian dengan apa yang di isi oleh siswa pada saat pengisian angket kejujuran. Dengan lembar observasi terdapat empat indikator yang diamati yaitu:

Tabel 7. Hasil Observasi Kejujuran Siklus 1

\begin{tabular}{llll}
\hline No & \multicolumn{1}{c}{ Indikator Kejujuran } & Sesuai & $\begin{array}{l}\text { Belum } \\
\text { Sesuai }\end{array}$ \\
\hline 1 & Membuat dan mengerjakan tugas dengan benar & 74 & 26 \\
2 & Tidak mencontek atau memberikan contekan & 77 & 23 \\
3 & Melaporkan kegiatan belajar secara transparan & 68 & 32 \\
4 & Tidak melakukan manipulasi & 74 & 26 \\
& Rata-rata & $73 \%$ & $27 \%$ \\
\hline
\end{tabular}

\section{Hasil Pengamatan Siklus 2}

Data nilai hasil belajar siswa pada siklus kedua antara lain pencapaian ketuntasan belajar sebesar $90 \%$, nilai tertinggi 98 , nilai terendah 67 , dan nilai rerata sebesar 89. Untuk mempermudah dalam memahami pencapaian hasil belajar pada siklus kedua tersebut, maka berikut ini disajikan tabel tentang hasil belajar pada siklus kedua.
Tabel 8. Nilai pada Siklus 2

\begin{tabular}{llc}
\hline No & \multicolumn{1}{c}{ Uraian } & Nilai \\
\hline 1 & Nilai tertinggi & 98 \\
2 & Nilai terendah & 67 \\
3 & Nilai rerata & 89 \\
4 & Prosentase ketuntasan & $90 \%$ \\
& belajar & \\
\hline
\end{tabular}

Adapun data tentang aktivitas siswa dalam proses pembelajaran pada siklus kedua yang berhasil dicatat oleh 
kolaborator sebagaimana tertuang dalam tabel berikut ini.

Tabel. 9. Hasil observasi pengelolaan pembelajaran Siklus 2

\begin{tabular}{lcl}
\hline \multicolumn{1}{c}{ Aspek } & Prosentase & Kategori \\
\hline Persiapan & $75 \%$ & Cukup \\
Pelaksanaan & & \\
Fase 1 & $92 \%$ & Baik \\
Fase 2 & $75 \%$ & Cukup \\
Fase 3 & $100 \%$ & Baik Sekali \\
Fase 4 & $100 \%$ & Baik Sekali \\
Fase 5 & $88 \%$ & Baik \\
Pengeloaan & & \\
Waktu & $100 \%$ & Baik Sekali \\
Suasana Kelas & $92 \%$ & Baik \\
Rata-rata & $90 \%$ & Baik \\
\hline
\end{tabular}

Siklus 2 mengalami peningkatan jika dibandingkan hasil siklus 1 dari $77 \%$ menjadi 90\%. Hal ini ditunjukan dengan adanya motivasi untuk perbaikan pada bagian yang kurang dengan beberapa masukan dan evaluasi dari observer, sehingga lebih memaksimalkan kegiatan pada siklus 2 .

Untuk lebih mempermudah pemahaman dalam melihat peningkatan hasil dari siklus 1 ke siklus 2 pada tiap kategori aspek yang diamati, perlu disajikan dalam tabel 10 dan gambar 2:

Tabel 10. Rekapitulasi Hasil Siklus.

\begin{tabular}{ccc}
\hline Kategori & Siklus 1 & Siklus 2 \\
\hline Hasil Belajar & 74 & 90 \\
Sikap Religius & 72 & 79 \\
Sikap Sosial & 67 & 76 \\
\hline
\end{tabular}

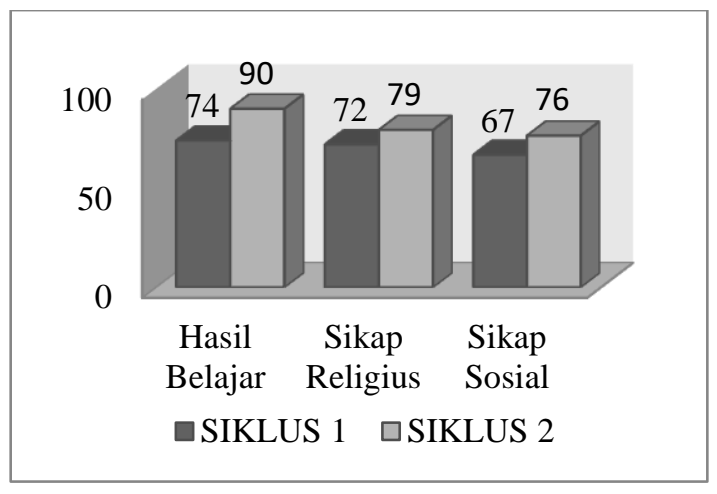

Gambar 2. Rekapitulasi Hasil Peningkatan tiap siklus

Sikap sosial mempunyai nilai paling rendah jika dibandikan dengan sikap religius dan hasil belajar, terdapat beberapa faktor yang bisa dicermati diantaranya: kurang terbiasanya sikap kerjasama yang terbangun dalam kegiatan kelompok. Siswa masih mengandalkan kemampuan masing-masing individu berbagi peran, tukar pendapat dan menghargai teman yang lain masih belum maksimal.

\section{Refleksi / Reflecting \\ Pada kegiatan refleksi, lebih} terhadap evaluasi hal-hal yang perlu diperbaiki dalam setiap tindakan, proses pembelajaran atau variable yang diteliti meliputi: hasil belajar, sikap religious dan sikap social. Berikut disajikan tabel 11 dalam mendeskripsikan serta membandingkan antar siklus.

Tabel 11. Deskriptif komparatif antara siklus 1 dan siklus 2

\begin{tabular}{llll}
\hline No & Uraian & \multicolumn{1}{c}{$\begin{array}{c}\text { Siklus } \\
\text { pertama }\end{array}$} & Siklus kedua \\
& & Tindak & Dalam proses \\
pembelajaran & Dalam proses \\
an & membelajaran \\
& & pembelajaran & menerapkan \\
& & terintegrasi & terintegrasi \\
& & sains islami & sains islami \\
& & mandiri & dengan \\
& & & bimbingan \\
& & & guru
\end{tabular}

\begin{tabular}{llll}
\hline 2 & Proses & Sebagian & Membuat dan \\
Pembel & besar siswa & mengerjakan \\
& aktif, dan & tugas dengan \\
& kreativitas & benar; \\
& siswa dalam & Tidak \\
& belajar & mencontek \\
& nampak & atau \\
& antusias, mulai & memberikan \\
& tercipta & contekan \\
& kondisi islami, & Melaporkan \\
& adanya & kegiatan \\
& kerjasama & belajar secara \\
& kelompok & transparan; \\
& Membuat dan & Tidak \\
& mengerjakan & melakukan \\
& tugas dengan & \\
\hline
\end{tabular}




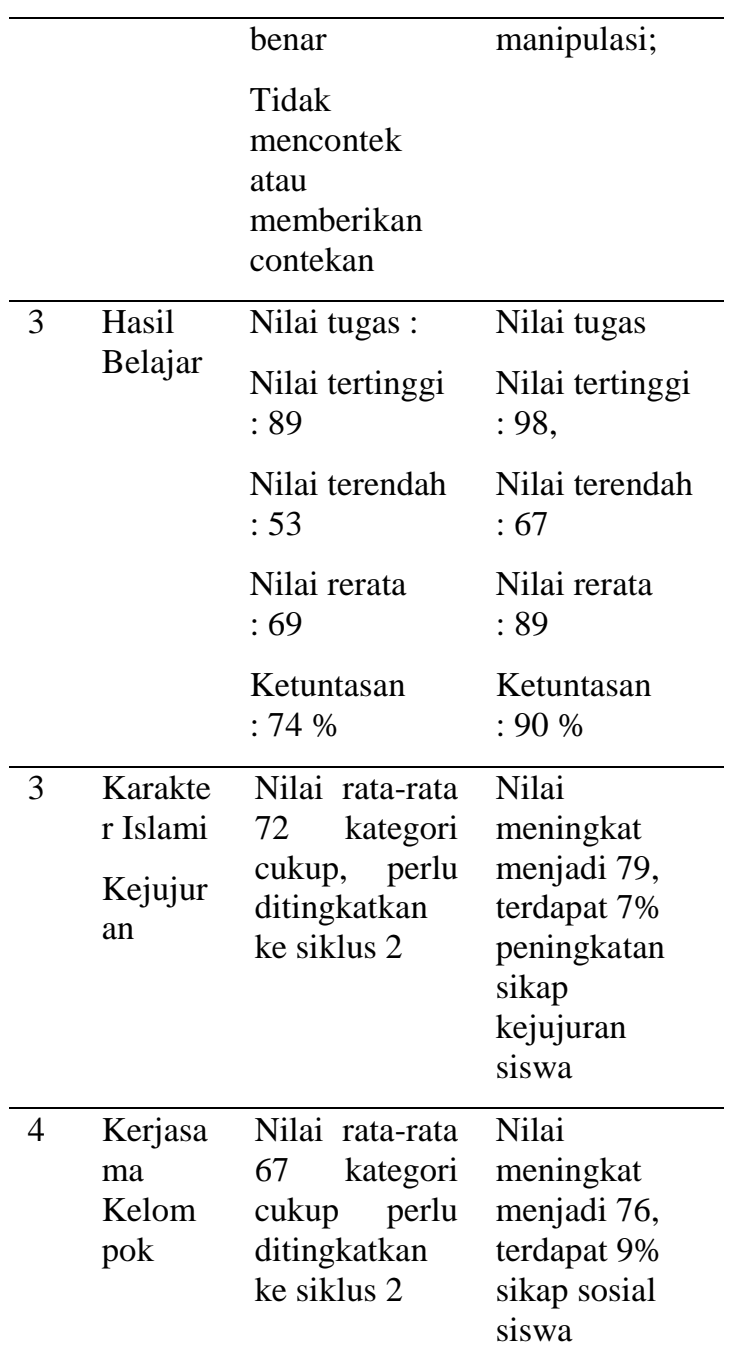

Pada siklus kedua terjadi peningkatan baik pada kualitas proses pembelajaran maupun pada hasil belajar siswa. Dalam proses pembelajaran,dengan adanya bimbingan guru, siswa menjadi semakin aktif, tidak ada lagi siswa yang mengantuk, dan kreativitas siswa dalam belajar nampak antusias dan kreatif.

Adapun hasil belajar siswa, mengalami peningkatan yang sangat signifikan. Nilai tertinggi meningkat sebesar 29\% dari 89 menjadi 98; nilai terendah meningkat sebesar $43 \%$ dari 53 menjadi 67; nilai rerata meningkat sebesar $64 \%$ dari 69 menjadi 89; dan pencapaian ketuntasan belajar juga meningkat sebesar $48 \%$ dari $74 \%$ menjadi $89 \%$. Untuk mempermudah memahami peningkatan kualitas proses dan hasil belajar siswa pada siklus kedua, maka berikut ini disajikan tabel refleksi siklus kedua. Karakter islami pada sikap religius berupa kejujuran meningkat yang dibuktikan dengan sajian berikut:

Tabel 12. Rekapitulasi Karakter Islami

\begin{tabular}{|c|c|c|c|}
\hline \multicolumn{2}{|c|}{$\mathrm{N}$} & \multirow[t]{2}{*}{ Sesuai } & \multirow{2}{*}{$\begin{array}{l}\text { Belum } \\
\text { Sesuai }\end{array}$} \\
\hline $\mathrm{O}$ & Indikator Kejujuran & & \\
\hline 1 & $\begin{array}{l}\text { Membuat dan } \\
\text { mengerjakan tugas } \\
\text { dengan benar }\end{array}$ & 87 & 13 \\
\hline 2 & $\begin{array}{l}\text { Tidak mencontek } \\
\text { atau memberikan } \\
\text { contekan }\end{array}$ & 84 & 16 \\
\hline 3 & $\begin{array}{l}\text { Melaporkan kegiatan } \\
\text { belajar secara } \\
\text { transparan }\end{array}$ & 81 & 19 \\
\hline 4 & $\begin{array}{l}\text { Tidak melakukan } \\
\text { manipulasi }\end{array}$ & 87 & 13 \\
\hline & Rata-rata & $85 \%$ & $15 \%$ \\
\hline
\end{tabular}

Terdapat beberapa catatan untuk penilaian keujuran yang diamati, kesesuaian hasil antara apa yang dituliskan pada angket dengan apa yang siswa lakukan pada saat kerjasama kelompok. Namun hal yang paling sulit dari keempat indikator kejujuran adalah tidak mencontek atau memberikan contekan serta melaporkan kegiatan belajar secara transparan. Perlu kesadaran dalam diri siswa yang semua itu memerlukan waktu dan proses mandiri dalam belajar.

Tabel 13. Refleksi siklus 2

\begin{tabular}{|c|c|c|}
\hline No & Uraian & Refleksi \\
\hline 1 & $\begin{array}{l}\text { Proses } \\
\text { Pembelajaran }\end{array}$ & $\begin{array}{l}\text { Keaktifan siswa } \\
\text { meningkat, jumlah } \\
\text { siswa yang mengantuk } \\
\text { berkurang, kreativitas } \\
\text { siswa meningkat }\end{array}$ \\
\hline 2 & Hasil belajar & $\begin{array}{l}\text { Nilai tertinggi naik } \\
29 \% \text { dari } 89 \text { menjadi } \\
98 \\
\text { Nilai terendah naik } \\
43 \% \text { dari } 53 \text { menjadi } \\
67 \\
\text { Nilai rerata naik } 64 \% \\
\text { dari } 69 \text { menjadi } 89 \\
\text { Ketuntasan naik } 48 \% \\
\text { dari } 74 \% \text { menjadi } \\
89 \%\end{array}$ \\
\hline
\end{tabular}




\begin{tabular}{lll}
\hline 3 & $\begin{array}{l}\text { Sikap religius } \\
\text { (Kejujuran) }\end{array}$ & Nilai capaian 79\% \\
\hline 4 & $\begin{array}{l}\text { Sikap sosial } \\
\text { (Kerjasama } \\
\text { Kelompok) }\end{array}$ & Nilai capaian 76\% \\
\hline
\end{tabular}

Peningkatan hasil belajar dari siklus pertama ke siklus kedua tersebut di atas tergolong cukup tinggi. Namun hal ini sangat wajar, karena pada siklus pertama kegiatan siswa dalam menerapkan Pembelajaran terintegrasi sains-islami dilaksanakan secara mandiri, tanpa bimbingan guru. Sedangkan pada siklus kedua kegiatan siswa tersebut dilakukan dengan bimbingan guru. Bimbingan guru ini terutama dilakukan pada waktu siswa melakukan diskusi kelompok, menciptakan kondisi kelas yang islami.

Tidak ada dikotomi ilmu (ilmu barat dan ilmu Islam). Ilmu adalah satu yang Allah ciptakan, tinggal bagaimana manusia menelisik (observasi dan riset) untuk menemukan dan mengembangkannya. (Aji, 2014). Pemaparan sains dalam buku-buku pelajaran dan penjelasannya oleh guru dan dosen sains, kadang telah menghilangkan Allah sebagai pencipta, dalam hal ini kegiatan diskusi lebih terhadap tindak lanjut dari hasil pengamatan yang meliputi: Tindakan, Proses Pembelajaran, Hasil Belajar, Sikap Religius dan sikap sosial.

1. Tindakan

Tabel 14. Rekapitulasi Tindakan

\begin{tabular}{llll}
\hline $\mathrm{N}$ & Kondisi & Siklus & Siklus kedua \\
$\mathrm{o}$ & awal & pertama & \\
\hline 1 & Dalam & Dalam & Dalam \\
& proses & proses & proses \\
& pembelajara & pembelajara & pembelajara \\
& n belum & $\mathrm{n}$ & $\mathrm{n}$ \\
menerapkan & menerapkan & menerapkan \\
& Pembelajara & Pembelajara & Pembelajara \\
& n & $n$ & $n$ \\
& terintegrasi & terintegrasi & terintegrasi \\
& sains-islami & sains-islami & sains-islami \\
& & secara & dengan \\
& & mandiri & bimbingan \\
& & & guru \\
\hline
\end{tabular}

2. Proses Pembelajaran
Tabel 15. Ilustrasi Proses Pembelajaran

\begin{tabular}{|c|c|c|}
\hline $\begin{array}{l}\mathbf{N} \\
\mathbf{0}\end{array}$ & Kegiatan & Ilustrasi \\
\hline 1 & $\begin{array}{l}\text { Kondisi } \\
\text { awal }\end{array}$ & $\begin{array}{l}\text { - Siswa kurang aktif; } \\
\text {-siswa mengantuk; } \\
\text { - kreativitas rendah. }\end{array}$ \\
\hline 2 & $\begin{array}{l}\text { Siklus } \\
\text { pertama }\end{array}$ & $\begin{array}{l}\text {-siswa aktif; kreativitas } \\
\text { nampak antusias; } \\
\text {-mulai tercipta kondisi islami; } \\
\text { adanya kerjasama kelompok; } \\
\text {-Membuat dan mengerjakan } \\
\text { tugas dengan benar; } \\
\text {-Tidak mencontek atau } \\
\text { memberikan contekan. }\end{array}$ \\
\hline 3 & $\begin{array}{l}\text { Siklus } \\
\text { kedua }\end{array}$ & $\begin{array}{l}\text {-Membuat dan mengerjakan } \\
\text { tugas dengan benar; } \\
\text {-Tidak mencontek atau } \\
\text { memberikan contekan; } \\
\text {-Melaporkan kegiatan belajar } \\
\text { secara transparan; } \\
\text {-Tidak melakukan } \\
\text { manipulasi. }\end{array}$ \\
\hline 4 & Refleksi & $\begin{array}{l}\text {-Dari kondisi awal ke kondisi } \\
\text { akhir terdapat peningkatan } \\
\text { keaktifan siswa dalam proses } \\
\text { pembelajaran. }\end{array}$ \\
\hline
\end{tabular}

3. Hasil belajar

Tabel 16. Peningkatan Hasil Belajar

\begin{tabular}{cccc}
\hline $\begin{array}{l}\text { N Kondisi } \\
\text { o }\end{array}$ awal & $\begin{array}{c}\text { Siklus } \\
\text { pertam } \\
\text { a }\end{array}$ & $\begin{array}{c}\text { Siklus } \\
\text { kedua }\end{array}$ & Refleksi \\
\hline $\begin{array}{c}\text { Ketun- } \\
\text { tasan } 51\end{array}$ & $\begin{array}{c}\text { Ketun- } \\
\text { tasan }\end{array}$ & $\begin{array}{c}\text { Ketun- } \\
\text { tasan }\end{array}$ & $\begin{array}{l}\text { Peningkatan } \\
\text { hasil belajar }\end{array}$ \\
& $74 \%$ & $90 \%$ & $\begin{array}{l}90,32 \% \text { dari } \\
\text { rerata } 61 \\
\text { menjadi } 89 .\end{array}$ \\
& & & \\
\end{tabular}

Tindakan penerapan Pembelajaran berbasis integrasi sains-islami dengan bimbingan guru terjadi peningkatan kualitas belajar maupun hasil belajar dari kondisi awal ke kondisi akhir. Nilai tertinggi mengalami peningkatan sebesar 38,70\% dari 86 menjadi 98; nilai terendah mengalami peningkatan sebesar $77,41 \%$ dari 43 menjadi 67; nilai rerata mengalami peningkatan sebesar $90 \%$ dari 61 menjadi 89; sedangkan pencapaian ketuntasan belajar mengalami peningkatan sebesar $51,61 \%$ dari $74 \%$ menjadi $90 \%$.

4. Sikap Religius dan sikap sosial

Tabel 17. Rekapitulasi Hasil Sikap Religius dan 
Sosial.

\begin{tabular}{|c|c|c|c|}
\hline $\begin{array}{c}\text { Aspek } \\
\text { yang } \\
\text { diamati }\end{array}$ & Siklus 1 & Siklus 2 & $\begin{array}{c}\text { Peningkata } \\
\text { n }(\%)\end{array}$ \\
\hline $\begin{array}{l}\text { Sikap } \\
\text { Religius } \\
\text { (Kejujuran } \\
\text { Siswa) }\end{array}$ & $\begin{array}{c}72 \\
\text { Angket } \\
73 \text { sesuai } \\
\text { Observas } \\
\text { i }\end{array}$ & $\begin{array}{c}79 \\
\text { angket } \\
85 \\
\text { sesuai } \\
\text { observas } \\
\text { i }\end{array}$ & $7 \%$ \\
\hline $\begin{array}{l}\text { Sikap } \\
\text { Sosial } \\
\text { (Kerjasam } \\
\text { a } \\
\text { kelompok) }\end{array}$ & $\begin{array}{c}67 \\
\text { angket }\end{array}$ & $\begin{array}{c}76 \\
\text { angket }\end{array}$ & $9 \%$ \\
\hline
\end{tabular}

\section{SIMPULAN DAN SARAN}

Berdasarkan data empiris, diketahui bahwa penerapan pembelajaran berbasis integrasi sains-islami dapat meningkatkan hasil belajar, sikap religius dan sikap sosial. Siswa dengan prosentase ketuntasan belajar sebesar 74 menjadi 90 . Sikap religius meningkat dari 72 menjadi 79 serta sikap sosial meningkat dari 67 menjadi 76 yang dibuktikan dengan indicator tidak mencontek atau memberikan contekan serta melaporkan kegiatan belajar secara transparan Dengan demikian, dapat disimpulkan bahwa baik secara teori maupun empiris, menerapkan pembelajaran berbasis integrasi sainsislami dapat ditingkatkan hasil belajar dan karakter islami pada sikap religious berupa kejujuran dan sikap sosial berupa kerjasama siswa kelas XI RPL pada mata pelajaran fisika semester gasal tahun pelajaran 2016/2017.

\section{UCAPAN TERIMAKASIH}

Ucapan terima kasih kepada segenap civitas akademika SMK Takhassus AlQur'an yang telah banyak membantu dalam penelitian, kepada Tim MGMP Fisika SMK se-Kabupaten Wonosobo serta kepada penyelenggara Workshop UNY yang telah membekali dalam proses pembuatan penelitian serta kepada Tim Dosen Fisika FITK UNSIQ.

\section{DAFTAR PUSTAKA}

Aji, S., \& Halal, R. (2014). Khazanah Sains dan Matematika dalam Islam. SALAM: Jurnal Sosial Dan Budaya Syar-I, l(1).

Ali, M. (2015). Pengembangan Modul IPA Berbasis Karakter Islami Melalui Pendekatan Saintifik Pada Tema Rotasi dan Revolusi Bumi Sebagai Implementasi Kurikulum 2013. Jurnal Inkuiri, 4(2).

Fakhry, J. (2010). Sains dan Teknologi dalam Al-Qur'an dan Implikasinya dalam Pembelajaran. Ta'dib, 15(1), 121-142.

Irwandani. (2016). Potensi Media Sosial dalam Mempopulerkan Konten Sains Islam. Tadris: Jurnal Keguruan Dan Ilmu Tarbiyah, 1(2), 173-177.

Masduki, M. (2015). Pendidikan Islam dan Kemajuan Sains: Historisitas Pendidikan Islam yang Mencerahkan. Jurnal Pendidikan Islam, 4(2), 261-275.

Mulyasa, E. (2010). Praktik penelitian tindakan kelas. Bandung: PT Remaja Rosda Karya.

Nasution, S. (2010). Metode Research (penelitian ilmiah). Jakarta: Bumi Aksara.

Rusdiana, A. (2015). Integrasi Pendidikan Agama Islam Dengan Sains Dan Teknologi. JURNAL ISTEK, 8(2).

Sugiyono. (2006). Metode penelitian Pendidikan pendekatan Kuantitatif, Kualitatif $d a \quad R \quad \& \quad D$. Bandung: Alfabeta.

Waston, W. (2014). Hubungan Sains dan Agama: Refleksi Filosofis Atas Pemikiran Ian G. Barbour. 